\title{
Interactions Between the Local and the Global: Brokers and go-betweens within the Portuguese State of India $(1500$ - 1700)
}

\author{
Amelia Polonia, \\ Associate Professor, \\ Faculty of Arts, University of Porto
}

\begin{abstract}
It is commonplace to locate the First Global Age in the period between 1500 and 1800 and present the European Overseas Expansion as one of the main levers of this process. However, interactions occurred locally and many localities were involved in the process. Recent and not sorecent historiography has stressed how cross-cultural and cross-imperial relations as well as cooperation and self-organization mechanisms have to be taken into consideration in order to understand the dynamics and the outputs arising from such a globalization process. This paper argues that the achievements required for the building of a global world depended to a great extent on agents of mediation, operating as formal and informal brokers and go-betweens. Following the fruitful path opened long ago by Michael Pearson, this contribution will develop an empirical analysis of the performance of such agents, within the Portuguese State of India, in the domains of economy, society and knowledge transfer.
\end{abstract}


Estado da Índia, sub-colonization, self-organizing networks, trade networks

I. The Portuguese "State of India" - formal and informal ways of empire building

It is still contentious what the expression "State of India" defines in terms of the Portuguese presence in the East and Far East. Some authors see it as a network of contacts and communications based on strategic hubs, in which the role of the state and the Portuguese crown was weak and highly heterogeneous, ${ }^{1}$ while others approach it as the expression of an intended project of empire building controlled by the Portuguese crown and its agents. ${ }^{2}$ In any case, the definition of the concept proposed by Luis Filipe Reis Thomaz remains pertinent and accurate:

"The State of India in the $16^{\text {th }}$ century designated not a well-defined geographical space, but a collection of territories, establishments, assets, individuals and interests that were administered, managed or governed by the Portuguese crown in the Indian Ocean and neighboring seas, and the coastal territories from the Cape of Good Hope to Japan."

The Estado da Índia is a concept created by the Portuguese State to refer to the Portuguese presence in the East, based on representatives of the Portuguese crown - the "Vice-Reis" (Viceroys) and on a military, financial and administrative system, governed by the Portuguese. The administrative model built up aimed both a monopolistic spice trade system and an effective central control of all agents travelling to the East whether they were officials, military personnel, adventurers, traders or members of religious orders. It should provide the State with control over the overall processes taking place from

1 L. F. Reis Thomaz, De Ceuta a Timor (Lisboa: Difel, 1994), 207-43.

2Francisco Bethencourt and Diogo Ramado Curto, eds., A Expansão Marítima Portuguesa, 1400-1800 (Lisboa: Edições 70, 2010), 1-18. 
the Middle East to the Far East. However, it was not what actually took place. The presence of the Portuguese in the East went far beyond State control. In general terms, the concept of Estado da Índiarefers to the interests that were officially governed by the crown, howeverit does not comprise nor does it exhaust the much broader reality of the Portuguese presence in the Indian Ocean and the neighboring seas. In fact, it does not include the non-official modes of settlement, which developed regardless of the State and, in some cases, even against the State.

In fact, even when the Portuguese crown sought to politically centralize the administration of overseas territories, whether in Brazil in 1542, with the establishment of the "GovernoGeral" (General Government), or in the East, with the creation, early on, of the "Estado da Índia," it has been proven that these structures were never able to exclude, or avoid, the informal and often marginal intervention of private parties. That is why Luiz Thomaz stresses the importance of the sub-colonization phenomena in the East, i.e. the creation of sub-colonies by the main colonies, which escaped central power control, both in administrative or economic terms.

Apart from the models of settlement as organized by the Portuguese crown in the Indian Ocean and Southeast Asia, spontaneous colonies of Portuguese traders also arose. These colonies proliferated throughout the Indian and Pacific Oceans, in places like, for example, Pattani (in Southern Siam); Negapatan; Saint Thomas of Mylapore (Coromandel Coast), and most particularly Macau. Indeed, Macau began as a territory controlled by a mercantile republic, which developed in connection with the establishment and consolidation of municipal power, through the Leal Senado. ${ }^{4}$ It was only later that the foundations of Portuguese sovereignty there were consolidated, by a concession of the emperors of China. Even so, the Portuguese crown was merelyrepresented by the Captains-General of the Goa Route to Japan.

This is quite a typical example of how self-organizing networks were successful, even in contexts where the Portuguese crown

4 Leal Senado - Portuguese for Loyal Senate, the seat of Macau's government. 
did not have a more forceful economic, military or administrative presence. The question remains how this was possible. Which were the ways and means by which the Portuguese settled in the Indian and the Pacific Ocean regions and remained even after the formal and institutionalized presence of the State of Indiahad disappeared?

The answers have been provided by several authors, among whom Michael Pearson plays a leading role. ${ }^{5}$ In this process, the establishment of networks of contact with local agents (merchants, political leaders, informants, pilots) was paramount. More recently, theories of cooperation and selforganizationhave brought theoretical insights to this analysis, by proposing new conceptual, but also new methodological frameworksdesigned to deepen those perspectives by strengthening their meanings. ${ }^{6}$

The worldwide framework produced in the First Global Age and the building of a global economy are, in fact, full of examples of cooperation and self-organization: national, international and intercontinental trade networks existed and are well known; ${ }^{7}$

5Michael Pearson, The Indian Ocean (New York: Routledge, 2003); Merchants and Rulers in Gujarat: The Response of the Portuguese in the Sixteenth Century. Berkeley (Los Angeles: University of California Press, 1976); Coastal Western India: Studies from the Portuguese Records. New Delhi: Concept Publishers, 1981; Port Cities and Intruders: the Swahili Coast, India, and Portugal in the Early Modern Era, Baltimore, The Johns Hopkins University Press, 1998; The Indian Ocean. London and New York: Routledge, 2003; The World of the Indian Ocean, 1500-1800: Studies in Economic, Social and Cultural History. Aldershot: Ashgate Publishers, 2005; Pearson, Michael and I. Bruce Watson, eds., Asia and Europe: Commerce, Colonialism and Cultures: Essays in Honour of SinnappahArasaratnam. South Asia. XIX, (1996). Special issue.

6Amélia Polónia, "Indivíduos e redes auto-organizadas na construção do império ultramarino português" in Álvaro Garrido; Leonor Freire Costa, Luís Miguel Duarte, eds., Economia, Instituições e Império. Estudos em Homenagem a Joaquim Romero de Magalhães (Coimbra:Almedina, 2012): 349-72;"Informal self-organised networks in the First Global Age. The Jesuits in Japan”. The Bulletin of the Institute for World Affairs Kyoto Sangyo University, 28 (Feb, 2013): 133-58.Cátia Antunes and Amélia Polónia, eds. - Beyond Empires.Global, Self-Organizing, Cross-Imperial Networks, 1500-1800. (Leiden: Brill, 2016) AméliaPolónia and CátiaAntunes, eds., Mechanisms of Global Empire Building (Porto: CITCEM/ Afrontamento, 2016); Ana Sofia Ribeiro, Early Modern Trading Networks in Europe. Cooperation and the case of Simon Ruiz (Abingdon, Oxon; New York: Routledge, 2016).

7AméliaPolónia, "Understanding the role of foreigners in the Portuguese overseas expansion through the lenses of the theories of cooperation and self-organisation". StoriaEconomica, XVIII, n. 2 (2015): 385-413. 
inter-confessional trade between Catholics, Protestants and Jewish is well documented; ${ }^{8}$ worldwide transference of goods and capital was based on cooperation patterns, as was the overall communication system; an active transference of news and information was a major pillar of cooperation in those days. In these processes, trust and reputation were extremely valuable, and gossip was a mechanism of both advertising and warning. In all of them, the commoners, pilots, seafarers, shipmasters, merchants, scientists and practitioners - from all sides of the cross-cultural, trans-political, and multi-religious possible combinations - were key elements of the system. The role of women,long neglected in this context, is now increasingly recognized as having been essential.

\section{Globalization on the making: the rise of a polycentric world}

How is this trend new or innovative? Since 1965, Donald F. Lach has compileda huge inventory of evidence on "Asia on the making of Europe", i.e., a comprehensive multi-volume catalog of Asian influences on Western culture. ${ }^{9}$ By scrutinizing European references to Asia published in the sixteenthcentury, the author surveys a vast array of writings describing Asian life and society, capturing and listing the images of Asia and the impact and uses of those images in European literature and art. While this work reveals profound influences of Asian societies and culture on the developing Western world, it is still oriented by a unidirectional analysis. The world scrutinized is still a linear world, and the analytical grid is the very same followed by the traditional Euro-centric approaches: a unidirectional transference resulting in an assimilation process able to enrich another world. What is required now is a different way of envisaging an emerging global world. This is a world in which frontiers still existed: political, religious, linguistic, of color and

8 Francesca Trivellato, Leor Halevi and CátiaAntunes, Religion and Trade in World History, 1000-1900 (New York: Oxford University Press, 2014).

9Donald F. Lach, Asia in the making of Europe (Chicago: Chicago University Press, 19651993). 3 vols; 
race, of gender, but whose construction depends on mechanisms that promote crossing borders and frontiers. ${ }^{10}$ In this "new" world, itself a mixture of different worlds nowin permanent contact, linguas (translators) and a full range of other cultural translators (such as missionaries, merchants, diplomats, men and women of science) have to be considered as crucial elements. Russell-Wood's classic overview in his seminal work, The Portuguese Empire, 1415-1808: A World on the Move, ${ }^{11}$ reveals the dimension of this trans-cultural, transcivilizational and cross-imperial network of exchanges initiated by the Portuguese. Russell-Wood identifies a global exchange circuit of products, goods and commodities, an evolving network of ports, economic centers and hubs, both in Europe and Asia, during this period.

The performance of the Portuguese as the first brokers at a global level, operating in all the oceans and continents, brought to Lisbon and other Portuguese seaports all over the world the status of a distributive platform for all the exotic products acquired overseas. Moreover, Portuguese seaports became points of departure for the distribution of European products in Africa, America and Asia. ${ }^{12}$ The dimension of this material exchange is novel: not because they are totally unknown, particularly concerning the transactions between Europe, Asia and Africa, but because these exchanges acquired a dimension, a time scale and a complexity so farunheard-of. They all became integrated markets, acting and reacting within a worldwide system of exchange, controlled by Europe and by Asia, to which the 'new worlds' of Africa and the Americas provided massive inputs, mostly as providers of raw materials, according to the well-known logic of colonial economies.

10AméliaPolónia, "Jumping frontiers, crossing barriers. Transfers between oceans. The Portuguese overseas expansion case study," in Rila Mukherjee, ed., Oceans Connect: reflections on water worlds across time and space (Delhi: Primus Books, 2012), 121-42. (Baltimore; London: The John Hopkins University Press, 1998). 
The products, goods and commodities handled by Portuguese traders, emigrants and sailors give credence to Russell-Wood's evaluation: 'Portugal [was] a major player in a global network of commodity exchanges and trade networks reaching from Danzig to the Zambezi and Mato Grosso to Manila.'13

In this game of exchanges, the Indian Ocean became a major player. It is well known thatthis dynamic pattern of transference wasnot totally novel in the Indian Ocean world. The Asian seas had been navigated by a myriad of individuals from different ethnic, cultural, religious and political backgrounds, well before the arrivalof the Portuguese in 1498. For a significant number of historians, with André Gunder Frank as one of the most relevant, the making of a global world in the Indian Ocean had become a reality long before the arrival of the Europeans. ${ }^{14}$ Port cities on the Indian subcontinent were, and were perceived as, a melting pot of different merchant communities - Muslims, Hindus, Armenians or Chinese traders, performing within networks connecting the Red Sea with the Pacific Ocean. ${ }^{15}$

The traditional perspective according to which the presence of European agents and powers in Asia after 1500, and mostly after 1600, with the Dutch, the British and the French settlements in Asia implied a violent rupture in the pre-existing trading systems has lately been questioned. However, theEuropean economic demands over the Asian markets created opportunities (or imposed demands) with an inevitable impact on agrarian markets (namely for spices) or local industries. Porcelains, tapestries, silk, or the Indian textiles are obvious examples, not to mention the pressure on the environment by the over-exploitation of natural resources, e.g. timber. ${ }^{16}$

This leads us to the conclusion that Asia should be perceived as a central universe in the making of Europe, as much as

13 Russell-Wood, The Portuguese Empire, 129.

14 A. Gunder Frank, Re-orient: global economy in the Asian age (Berkeley: University of California Press, 1998); Sanjay Subrahmanyan, Mughals and Franks. Explorations in Connected History (New Dehli: Oxford University Press, 2011).

15 C. Lockard, "The sea common to all": maritime frontiers, port cities, and Chinese traders in the Southeast Asian Age of Commerce," Journal of World History 21, no. 2 (2010): 219. 
Europe, which was undoubtedly an agent of change responsible for the emergence of new balances of power and new economic grounds in Asia ${ }^{17}$. The search for new markets and the interplay among European powers led to the emergence of new economic centers, until then either nonexistent as such, or seen as second or third range hubs: Macau, Manila, Batavia are cases in point.

If one focuses on the less-studied areas of trading (in a broader sense) and on how the Europeans were forced to adapt to the trade systems pre-existing in the East, we have to deal with another central concept: trade networks. Asian historiography has strongly emphasized how different groups of merchants circulating throughout the Asian Seas performed mostly within diaspora groups to which they belonged, with the Armenians as a case in point. Within this framework, Islamic traders alsoaccomplished the role of transfer agents within the Indian Ocean, within more formal and central circuits of trade, connecting Southeast Asia with the Indian sub-continent, the Arab Peninsula and East Africa, based on the dissemination of Islamic power over territories bordering the Indian Ocean. ${ }^{18}$ At the same time, networks of knowledge and the strengthening of social bonds were pre-conditions to the consolidation of all

16 Richard P. Tucker, "The Depletion of India's Forests under British Imperialism: Planters, Foresters, and Peasants in Assam and Kerala," in Donald Worster, ed., The Ends of the Earth Perspectives on Modern Environmental History, Studies in Environment and History (Cambridge; New York: Cambridge University Press,1988), 118-40; Greg Bankoff, "One island too many: reappraising the extent of deforestation in the Philippines prior to 1946," Journal of Historical Geography33, no. 2 (April 2007): 314-34.

17Michael Pearson and Blair M. Kling, eds., The Age of Partnership: Europeans in Asia before Dominion (Honolulu: The University Press of Hawaii, 1979); Michael Pearson, Before Colonialism: Theories on Asian-European Relations, 1500-1750 (Delhi: Oxford University Press, 1988).

18 K. Chaudhuri, Trade and Civilization in the Indian Ocean: an Economic History from the Rise of Islam to 1750 (Cambridge: Cambridge University Press, 1985); G. Bouchon and B. Lombard, "The Indian Ocean in the Fifteenth Century", in A. das Gupta and M. Pearson, eds., India and the Indian Ocean, 1500-1800 (Delhi: Oxford University Press, 1987), 46-70; P. Risso, Merchants and faith: Muslim Commerce and Culture in the Indian ocean (Boulder: Westview Press, 1995); C. Lockard, Southeast Asia in World History (New York: Oxford University Press, 2009), 34-36, 62-73; K. Hall, A history of Early South East Asia: Maritime Trade and Societal Development, 1000-1500 (Plymouth: Rowman \& Littlefield Publishers, 2011). 
kinds of transfers, essential to the building of this global world. In all those dynamics, locality was essential. Currently, history of science has been discussing the mechanisms of production of a syncretic knowledge resulting from acquisitions provided by local agents in Asia, Africa and the Americas. In this context, debates on the role of the go-betweens, the intermediaries among European and local bearers of knowledge are taking on a central role. Cultural patterns towards syncretism, requiring the comprehension of local processes of knowledge production, as much as the mechanisms of global circulation of persons, commodities, information and knowledge, are now receiving attention, opening new avenues of enquiry. ${ }^{19} \mathrm{New}$ analytical proposals are expanding the parameters of research, according to which some aspects of modern science and the modern world are understood as global while being the result of intricate local processes. Circulation and locality became thus core concepts of these theoretical approaches. The analysis of processes that combine polycentric and local production of knowledge with its global circulation turns out to be fruitful in historical analysis and can be documented, as it has been, with emphasis in the Indian Ocean world.

Trying to add empirical evidence for what has been stated, this paper will now focus on three kinds of brokers and gobetweens, from formal to informal, from groups to individuals, that will enable us to illustrate the dynamics under scrutiny within the scope of the Portuguese State of India. The first will be taken from the experience of the Jesuits in Japan; the second from the performance of networks of New Christians and their connections with Armenian networks; the third will synthetically scrutinize the role of women as intermediaries in the State of India - all of them providing useful examples on

19 Kapil Raj, "The Historical Anatomy of a Contact Zone: Calcutta in the 18th Century",Indian Economic and Social History Review, 48 (2011): 55-82; "Introduction. Circulation and Locality in Early Modern Science", British Journal for the History of Science, 43, 4 (2010): 513-517; "Mapping Knowledge Go-Betweens in Calcutta, 1770-1820" in Simon Schaffer, Lissa Roberts, Kapil Raj \& James Delbourgo, eds., The Brokered World: Go-betweens and Global Intelligence, 1770-1820 (Sagamore Beach, MA, Science History Publications: 2009), 105-50. 
how, acting locally, individual agents contribute to the building up of a global world.

III. The Jesuits in Japan - political and economic intermediaries

The Jesuits were the only Portuguese agents to whom permission had been given to settle in Japan, until they were formally expelled from the territory in 1614. It is widely acknowledged that, with regard to Japan, neither the crown nor the vice-royalty had any role in the expansion and consolidation of the Portuguese presence in that territory, as they did not interfere with the final outcomes of the process, which ultimately led to the expulsion of the Portuguese from Japan, in 1639 , after previous expulsion edicts in $1614 .{ }^{20}$ The Portuguese crown delegated complete authority to the Jesuits, on whom the achievement of successful or unsuccessful Portuguese relations with Japan mainly depended, whether in religious, political, cultural or commercial terms.

Introduced by local agents, among whom wereChinese pilots, exploiting traditional trade channels and opening new ones, the Portuguese traders, adventurers, mercenaries and outsiders, penetrated a new region and contributed to consolidating, in the second half of the sixteenth century, one of the most profitable and rewarding trade routes of the time: that connecting Malacca to Japan. This traffic, at first maintained on a smuggling basis, provided the Portuguese with a very advantageous position in the inter-Asian trade, for which they held a monopoly for almost a century. Their cargo capacity and their superior weapons, added to the internal political circumstances in the Far East, guaranteed the Portuguese vast opportunities.

Cooperation was an essential feature of this process. In fact, from the beginning, the Portuguese crossed unknown waters with the assistance of native pilots. Arab, Guajarati, Javanese and Malay pilots were present on Portuguese voyages from Malabar to Ceylon, Malacca, the Sunda Islands, Java, the 
Moluccas, Sumatra and Siam, much as Chinese pilots were frequently used for the Malacca-Macau-Japan run. ${ }^{21}$

In 1543, two Portuguese, one of them allegedly Fernão Mendes Pinto, a trader and an adventurer, were passengers on a Chinese ship that landed at the Japanese island of Tanegashima. At a time when trade between the Chinese and Japanese was affected by conflicts and warfare, the Portuguese soon assumed the role of intermediaries between the two. ${ }^{22}$

Besides being involved in the Chinese/Japanese trade, the Portuguese brought some new products to Japan: tobacco, sweet potatoes, clocks and guns. The introduction of European guns was to play a major role in the evolution of Japanese internal politics. In a context of generalized civil war within a feudal political structure, where power was being disputed among local landlords, expertise in handling European rifles offered some military leaders an obvious advantage. ${ }^{23}$

The namban-jin (the southern barbarians), as the Japanese called the Portuguese, centered their activity on the island of Kyûshû, creating a business settlement in Nagasaki by 1571 . The Jesuits would later be in charge of the administration of the settlement, by decision of the local Christian landlord, BartolomeuSumitada.

The Jesuit missions in the territory introduced some formal structures in this framework. In 1549 Jesuit missionaries led by Francis Xavier arrived in Japan, intent on founding missions and converting the Japanese to Christianity. Unlikethe merchants, and given their mission of widespread evangelization, their action would ultimately have a major impacton Japan. The Jesuitssought toestablishpermanent

21 A. J. R. Russell-Wood, A World on the Move: the Portuguese in Africa, Asia, and America, 1415-1808 (New York: St. Martin's Press, 1993),15.

22 León Bourdon, Les Routes des Marchands portugais entre China et Japon au milieu du XVIé. siècle. (Lisboa: Gráfica Lisbonense, 1949); John Ehitney Hall, ed., The Cambridge History of Japan (Cambridge: Cambridge University Press, 2003), IV, 302-72; João Paulo Oliveira e Costa, A descoberta da Civilização japonesa pelos Portugueses (Lisboa: Instituto Cultural de Macau/ Instituto de História de Além Mar, 1995), 119-30.

23 Geoffrey Parker, The military revolution: military innovation and the rise of the West, 1500-1800 (Cambridge; New York: Cambridge University Press, 1996), 140, 210. 
missions and to spread throughout Japan. In 1551, Francis Xaviertravelled to thecapital,Miayko, trying to gain a foothold in Japan's political center, ${ }^{24}$ and in 1554, Fernão Mendes Pinto, a temporary member of the Jesuits, was sent by the Vice-Roy as an ambassador to the Daimyo of Bungo. ${ }^{25}$ None of these "official" missions were to have a significant impact on the settlement of the Jesuits.

The Jesuits eventually engagedin the Japanese political infighting, as they soughtto obtain the benefitand support oflocallandlords. The fact that by 1588 there were more than 150,000 baptized Japanese illustrates the success of the Society's strategy. ${ }^{26}$ With the Jesuits, religion, politics and ultimately, trade, became a structural trend, emulating, again, a well-known shift in Portuguese overall expansion, which was meant to have a major expression in the Japanese missions.

At the time, this intense involvement and the strong position achieved by the Jesuits in the trade circuits involving Japan was subject to active and heated debate and was strongly criticized at several levels. Objections came from merchants, who were affected by the Jesuits' expertise and privileges. Local landlords used them as trade intermediaries but suspected their duplicitous behaviors. Additionally, they met with the disapproval of other ecclesiastic agents, in particular other religious orders; and of the king himself. Philip III promulgated edicts, in 1607, 1609 and 1610, forbidding the Jesuits to trade in Japan. However, the prohibition never had any real effect, and was revoked by July 1611. The reason given was that, unlike the other missions in the East, the Jesuits were not provided with regular and sufficient funding so

24 Hall, The Cambridge History of Japan, IV, 312-16.

25João Paulo Oliveira e Costa, O Japão e o Cristianismo no Século XVI. Ensaios de História Luso-Nipónica (Lisboa: Sociedade da Independência de Portugal, 1989), 110-11. 
that trade was the main basis for the implementation of Christianization and missionary activity in Japan. ${ }^{27}$

Regardless of the reasons, it is impossible to separate religion from trade when considering the presence of the Jesuits in Japan, as much as it is difficult to separate formal and authorized from informal and unauthorized participation of Jesuits in the trade involving Japan. ${ }^{28}$ Macau was a major hub in those trade circuits. Macau was, by the time of the first contacts with Japan, a merchant republic, still uncontrolled by the Portuguese State of India. The city developed quickly from an unknown and marginal place to a pivotal point in the maritime trade routes of the Far East, due to individual initiative. When Portuguese mediation between China and Japan, through Macau, gradually went beyond the status of an illegal, irregular, parallel circuit, to become a regular maritime trade business, the kingappropriated this route byroyalprovision, assigning it to noblemen as a rewardfor services rendered. ${ }^{29}$ Local merchants of Macau had to negotiate the freight of their merchandise with the carrack captains, according to pre-established rates, defined by the merchants' wealth. In a measure seen as beneficial only to some of the richest traders, the ecclesiastic administrator of the territories of Macau, China and Japan, Melchior Carneiro, a Jesuit himself, in the 1570's tried to improve the attribution of freights. He included the Jesuits in this proposal, as supervisors of a new model of trade, based on a contract with fixed amounts (the contrato de armação), in which the participation of smaller traders, as well as the Misericordia houses and other non-profit-making institutions, like the Jesuits themselves, would be included.

Later on, identical patterns tended to be organized in Nagasaki, where the main cargos were shipped, and where free trade was replaced by the pancada contract, i.e. the overall cargo of silk would be sold at a single price, trying to avoid speculation. Again, the Jesuits, in the person of João Rodrigues Tçuzzu,

27Sousa, Japão e os Portugueses (1580-1641), II, 413-14.

28Polónia, "Informal self-organised networks."

29 Michael Cooper, "The Mechanisms of the Macau-Nagasaki silk trade," in MonumentaNipponica (Tokyo: University of Sophia, 1972), XXVII, no. 4. 
became the main regulators of this system, with João Rodrigues as representative of Tokugawa leyasu. Mediators between Portuguese and Japanese traders, they also acted as brokers and trade agents for the Japanese landlords. This position would allegedly benefit their own interests, since they were themselves involved in the trade, with significant amounts of cargos.

With their extensive knowledge of the Japanese language, economy and markets, and well connected with local traders as well as belonging to a network operating within the overall Portuguese Padroado, the Jesuits were able to obtain credit to apply to financial and commercial speculation. In fact, they were in a privileged position as brokers, and took advantage of it, acting as traders as much as they did as missionaries.

The Jesuits simultaneously participated in illegal trade, as members of the Company or as individual agentsinvolved in silver imports to Macau and China. Numerous records indicate that they had cargos delivered in illegal ships, part of an underground trade that ran parallel to the crown's carracks. Besides the trade led by the Society, allegedly conducted to guarantee the missions in Japan, the activities of individual Jesuits, both European and Japanese, should be acknowledged, within the frame of a totally illegal flow of merchandise and money, moving significant amounts of merchandise. ${ }^{30}$

The analysis of the Jesuit performance in Japan has to take into account another relevant topic, besides politics and trade:the Jesuits' missionary activity and acculturation processes in Japan. We do not intend to thoroughly review the evangelization strategies followed by the Jesuits, or analyze their acculturation processes. ${ }^{31}$ However, we cannot disregard another kind of networking: the individual interactions that took place between the European and the Japanese Jesuits as brothers and as auxiliary personnel of the Jesuit missions. This

30Sousa, O Japão e os Portugueses (1580-1641), II, 333-425.

31See, on these topics, Léon Bourdon, La Compagnie de Jésus et le Japon. 1547-1570 (Paris : FCG-CCP; CNCD, 1993) and COSTA, Japão e o Cristianismo no Século XVI; Descoberta da Civilização japonesa. 
leads to another area of research, inter-culturality, which is an additional dimension of globalization.

This specificity of the Jesuit mission in Japan, its uniqueness with regard to the main centers of authority of the Portuguese empire in the East; its sporadic contacts with the Portuguese merchants coming from Macau once a year; its marginality regarding the main epicenters of evangelization, its peculiar status within the Portuguese Padroado in the East - all worked together to make the Jesuits largely dependent on the internal conditions in Japan itself. This raised a number of problems, along with significant advantages, since the Jesuits' missionary activity was not directly associated with a foreign political power intent to impose over Japan.

The Jesuits depended thus, simultaneously, on the protection and welfare of the daimyos and on cooperation and assistance from local agents. As regards evangelizationthey pursued a twofold strategy: the adoption of the Buddhist system of the "dógicos" or dojucus, who acted, not as priests, since they were not ordained, but as co-operators, as assistants even in the domain of catechization; and the formation of an indigenous clergy, by the admission of Japanese as members to the Society. Their number, in both cases, increased over time, and the dependency of the European Jesuits on these elements became crucial to the mission's sustainability. ${ }^{32}$

The decision to enforce the constitution of a local clergy was constantly debated. From the correspondence and reports, it seems clear that, while European Jesuits in Japan actively defended it, it met with strong reaction from the institutionalized hierarchy in Europe, particularly in Rome. The massive establishment of a local clergy was still exceptional in the overall framework of the Portuguese Padroado, mostly regarding the Jesuits, whose selection criteria, even in Europe, were very strict.

The need to follow a different policy in Japan increased from 1587 onwards and particularly in 1614, when the European

32João Paulo Oliveira e Costa, "Os Jesuítas no Japão (1549 - 1598). Uma análise estatística," in O Japão e o Cristianismo no Século XVI. Ensaios de História Luso-Nipónica (Lisboa: Sociedade da Independência de Portugal, 1989), 17-47. 
missionaries were expelled. By then, the Jesuits understood that the maintenance of Christianity in Japan depended on the activity of indigenous priests: the number of ordinations increased, even though the Jesuits would often return, disguised as merchants and sailors, to their previous domain of activity. ${ }^{33}$

Although the Jesuits admitted and implementedthe ordinations of local priests, and depended on a significant number of dógicos or dojucus in their activity, it is clear that a sense of criticism toward these members, a certain degree of incomprehension of their habits and permanent doubts as to their discipline and obedience prevailed, as can be seen in the Jesuit letters. An unavoidable Eurocentric position and incomprehension of the daily habits and psychological profile of the local collaborators appears in most of them, particularly after 1580.

The acomodatio concept, which expresses a policy toward the total integration of the Japanese indigenous priests into the Society, does not seem to have really happened: on the contrary, the European priests maintained a sense of superiority, and made it difficultfor the local members to accede to higher positions in the hierarchy. Formal claims, and the use of political ploys by the Japanese priests in order to circumvent the difficulties felt in the missions, using political pressure to achieve their aims, createdinternal tension. The repeated written testimonies reflect, once again, the overall mechanisms of cooperation at hand: behaviors of collaboration, deception and duplicity co-existed in daily life. The frequent abandonment of the mission, both by dojucus and Japanese priests, shows the lack of accommodation. ${ }^{34}$

Inter-culturality worked in fact in both ways, and seemed to be more effective with regard to the European Jesuits: acculturation was a major trend in their presence in Japan, and it was inevitable. They tended to adapt to the local environment in ways incomprehensible to all of the Society's European visitors. These were even to doubt who were the converted: the

33Costa, “Os Jesuítas no Japão (1549 - 1598)," 17-47.

34For further details see Sousa, O Japão e os Portugueses (1580-1641), I, 77-104. 
Japanese to Christianity, or the Jesuits to Japanese culture. Language, food regime, architectural design of the Jesuit houses and churches; clothes; daily schedules; the nature of self-punishment and corporal punishments toward third parties; ${ }^{35}$ all seemed to be more Japanese than European. ${ }^{36}$

Nevertheless, the Jesuits were part of the formal and institutionalized framework of the State of India and the Portuguese Padroado.

IV. Networks on the margins of the system: Jews and NewChristians as brokers in trade

The Portuguese crown intended to control all departures from Lisbon to the East. Only individuals licensed by the crown were entitled to travel to India. The law further restricted European settlers by acknowledging only three categories of legal residents in Asia: soldiers, casados (married men), and clergymen, including priests and missionaries. In addition, the law established further restrictions on certain groups. It barred all foreigners from Asia and any persons suspected of unorthodox beliefs, including the Portuguese New Christians, descendants from former Jews forcefully converted to Christianity.

The reality was, however, far from that stipulated by the law. The persecution of Jews in the Iberian Peninsula and the intolerance that new converts faced in Portugal engendered waves of migration to the Portuguese territories in the East, resulting in and proved by the creation of the Tribunal of the Holy Office in Goa in 1560. The itinerary of Garcia de Orta, the Portuguese physicist, and his family is but one example of this diaspora. This migration took place not just for religious reasons, but also for economic reasons. Seeking new

35Archivum Romanum Societatis Iesu, Collection Japonica and Sinica, 2, fl. 165. Cit. Sousa, O Japão e os Portugueses (1580-1641), I, 74.

36Rui Loureiro, "Turning Japanese? The experiences and writings of a Portuguese Jesuit in the $16^{\text {th }}$ century Japan," in Dejanirah Couto and François Lachaud, dir., Empires Eloignés (Paris: École Française de l' Extrême Orient, 2010), 155-68; João Paulo Oliveira e Costa, Japão e o Cristianismo no Século XVI. 
opportunities for trade they created or activated highly lucrative business networks.

The presence and circulation of numerous Jewish, cryptoJewish and New Christians in the East, especially in the seat of Portuguese political power, Goa, has been documented in various ways, from the early decades of the sixteenth century onwards. The first known reference to fluxes of illegal immigration by New Christians to India dates from 1519 and this phenomenon resulted in the promulgation of crown legislation to control such immigration. ${ }^{37}$ These flows tended to increase in the 1530s, and available documentation corroborates their geographic dispersal. Identifiable destinations of these agents includeGoa, Cochin and Hormuz, but also Cambay, Bassein, Malacca, and even Japan and China. ${ }^{38}$

This trend is corroborated by a letter, dated 1539, from Dr. Jerónimo Dias to the king, in which he noted not just the number but the internal power of these New Christians, especially in the business world:

"And they are here in no small numbers in this city and in Your Highness' other settlements and fortresses and they are very harmful. Those who are here are involved in all sorts of contracts and trade and other activities because everything is in their hands. There are not any good men here who can live with them. All these carracks come over here full of those unauthorized and clandestine men. We do not believe that Your Highness is aware of this because they bribe everyone with gifts and money and bypass all the restrictions that might have been imposed in these matters by Your Highness." 39

37 See the letter published by AntónioBaião, in A Inquisição de Goa. Tentativa de História da sua Origem, Evolução e Extinção (Lisbon: Academia das Ciências de Lisboa; Imprensa da Universidade de Coimbra, 1949), I, 17-18.

38A. Cunha, A Inquisição no Estado da Índia: origens (1539-1560) (Lisbon: Arquivos Nacionais-Torre do Tombo, 1995), 26.

393 December 1539 - Goa (TT.CC. I Parte, Mç. 66, doc. 47, fl. 15-16), published in Cunha, Inquisição no Estado da Índia, 253. 
The grand inquiry held in Cochin in 1557 and the proposal by the Cardinal-Prince Dom Henrique to create a Tribunal of the Inquisition in Goa (which was established in 1560) proves the presence of a large number of New Christians scattered throughout the vast Estado da Índia. A significant number of craftsmen, storekeepers and moneylenders were identified amongst their ranks, but they were also bureaucrats, leading merchants and tenant farmers. Some New Christians were even creditors of the Estado da Índia. ${ }^{40}$ The New Christians known to have lived in the Orient included physicians, doctors and pharmacologists, the most outstanding example beingGarcia de Orta. ${ }^{41}$

They expanded their networks throughout the East and Far East, as well as their international ties, especially with Italy, Germany, the Low Countries and, in the case of the eastern community, with North Africa and the Great Turk. ${ }^{42}$ These networks encompassed diplomatic circuits, espionage, and commercial and financial acumen, as well as knowledge and the circulation of cultural products, including books and maps.

Their connections with Armenian merchants and Armenian communities $^{43}$ are equally striking. The latter performed throughout the Ottoman empire the way the former did within the Portuguese - both were pushed to the margins of the system; both were persecuted or hardly tolerated for their

40Cunha, Inquisição no Estado da Índia, 41-42.

41 One can note that one of the first cases of migration was, precisely, that of the parents of Cristóvão da Costa, a New Christian doctor, born in Mozambique, in 1515. Augusto da Silva Carvalho, "Garcia de Orta," Revista da Universidade de Coimbra XII (1934): 125.

42CUNHA, Inquisição no Estado da Índia, 39-49.

43Alberto Baena Zapatero and Xabier Lamikiz, "Presencia de una Diáspora Global: comerciantes armenios y comercio intercultural en Manila, c. 1660-1800," Revista de Indias 262 (2014): 693-722; Sushil Chaudhury and Kéram Kévonian, Les Arméniensdansle commerce asiatique au début de l'èremodernel Armenians in Asiantrade in theearlymodern era S/l (Bordeaux: Mayson de les Sciences de 1'Homme, 2008); Sebouh Aslanian, From the Indian Ocean to the Mediterranean. The Global Trade Networks of Armenian Merchants from New Julfa (Berkeley: University of California Press, 2011); Ina Baghdiantz McCabe, "Small Town Merchants, Global Ventures: The Maritime trade of the New Julfan Armenians in the Seventeenth and Eighteenth Centuries," in Maria Fusaro and AméliaPolónia, eds., Maritime History as Global History (St. John's; Newfoundland: International Maritime Economic History Association, 2011), 125-57. 
religious beliefs; both tended to be monogamist as far as family connections were concerned, and both were totally open to all kind of intersections and agreements with "others" as for business and enterprise.

By performing as agents of trans-imperial connections (in this case, intersecting the Portuguese and the Ottoman empires),both communities became essential elements of empire building. By operating frequently on the margin of the system, they performed in a world in which they permanently crossed frontiers. Those agents were able to open new avenues of trade interacting with each other and with local merchants, within self-organized networks of trade, escaping as much as possible from the control of state and empire.

Both communities reinforced, in fact, communication and trade connections within a multi-cultural, multi-lingual and multireligious set-up, as the Indian Ocean and the adjacent seas then were. Their role as línguas, as translators, their availability to connect, by themselves or by their partners in international and even global networks, different localities, in Asia, the Arabian world and Europe make them appear as privileged agents of sustainability of the Portuguese presence in the East and Far-East, even if, paradoxically, their presence was not accepted, or even recognized, by the formal entities representing the Portuguese State of India. They became essential builders of a global world, by connecting different localities and by performing as connectors of amazingly different localities. All that in a world that was, in fact, polycentric and in which the Indian Ocean was, in the time under consideration, one of the most important centers.

\section{Women as go-betweens in the State of India ${ }^{44}$}

A traditional historiography focused on men, mostly those labelled as political and military "heroes", tends to forget

44 For further developments see AméliaPolónia and Rosa Capelão, "Connecting worlds. Women as intermediaries in the Portuguese Overseas Empire.The State of India, 1500-1600," in Tanja Bührer; Flavio Eichmann, StigFörster and BenediktStuchtey, eds., In the Shadows of Empire. Local Co-Operation in a Global Framework (Oxford; New York: Berghahn Books, Forthcoming in 2017). 
another driving force of Portuguese settlement in the East: women, both Portuguese and autochthone.

For the Portuguese, the colonization strategies orchestrated by the Portuguese government embraced not only the "orphans of the king", daughters of formal agents of empire building, lower nobilitymembers deceased while at the service of the crown, but also those convicted of prostitution in the kingdom, or those housed in the various Refuges of Santa Maria Magdalena scattered around the country. Former prostitutes or marginalized women were transformed into reluctant instruments of settlement strategies of which they were essential elements. ${ }^{45}$ In the State of India, the former seem to have clearly overtaken the latter, whose presence in Africa and Brazil seems to be more conspicuous.

On the whole, the number of Portuguese women in the East seems to have been quite significant. From the late sixteenth and early seventeenth centuries, local recommendations from Goa strongly suggested that more Portuguese women should not be sent to marry there, since the marriage market was saturated with local orphans, white and mestizas, of Portuguese descendants ${ }^{46}$ - all of them considered Portuguese. From the beginning of the Portuguese formal settlement in the East, official mating strategies were embraced. Afonso de Albuquerque, the second governor of India (1509-1515) aimed to increase the number of Portuguesecasados ${ }^{47}$ by marrying

45Coates, Degredados e órfãs.

46José Justino de Andrade Silva, Collecção Chronologica da Legislação Portugueza 16571674 (Lisbon: Imprensa de J. J. A. Silva, 1856), 273; Letter of the City Council of Goa, 31 10-1524 (Cf.) in António da Silva Rêgo, Documentação para a História das Missões do Padroado Português do OrienteÍndia (Lisbon: Agência Geral das Colónias, 1947-1958), II, 36.

47 The term casadosrefers to those Portuguese who were encouraged to settled in the Eastern territories, through marriages with local women. They became residents of the places where they married, as they were given land to settle. They were not obliged to military service, but were forced to defend some places in times of conflict. They were granted certain privileges in relation to trade. In some cases they were transformed into a local elite, becoming municipal officers and assuming responsibilities in social institutions such as Casas da Misericordias(charitable institutions founded in Portugal at the end of the 15th century by laymen and established all over the Portuguese overseas territories). The first promoter of this policy in the Estado da Índia was Afonso de Albuquerque, Portugal's Governor and Vice-Roy of India between 1509-1515. As for itseffectiveimpact, Albuquerque explains it in a Letter to 
them to local women. The relevance of this policy can be measured from the opposition it encountered within the State of India and the division between its supporters and opponents. Basically it implied the conversion of local women, Hindu or Muslim, to Christianity, and their endowment to marry Portuguese officers, both civil and military. ${ }^{48}$ Ideological debates on the meaning of such policy as the expression of the Portuguese propensity to intermingle with autochthonous local populations are still on-going. ${ }^{49}$

Albuquerque clearly hierarchizes theautochthone women, separating those suitable for marriage from those who were captives and sold as slaves, even if the frontier is not always clear. ${ }^{50}$ Many of the local women, taken by the Portuguese as part of marriage strategies, were indeed captives, since they were taken from their families as a conquest ransom. Those were usually Muslims, converted to Christianity. But they might as well be Hindu, either forcefully converted or encouraged to marry Portuguese soldiers and officers. The sources also reveal a policy of forceful marriages, with weddings being celebrated against the brides' will. ${ }^{51}$ This was precisely one of the arguments used against Afonso de Albuquerque by his opponents.

In parallel, and besides the official marriage market, there was a significant number of captive and slave women who became essential to settlement purposes in the East. These were sold

D. Manuel, 1-4-1512, in Rêgo, Documentação para a História das Missões, I, 145-52.

48Letter of 22-12-1510 in Rêgo, Documentação para a História das Missões, I, 118. All translations from Portuguese are by the authors.

49 Cf. for instance the debate on the Gilberto Freyre'sLusotropicalism as the Salazar regime ideological flag to justify colonial policies in Brazil and Africa. To furtherdevelopments, see: Cláudia Castelo, O modo português de estar no mundo: o luso-tropicalismo e a ideologia colonial portuguesa: 1933-1961 (Porto: Afrontamento, 1999).

50Letter of Afonso de Albuquerque to D. Manuel of 4-11-1514, in Rêgo, Documentação para a História das Missões, I, 119-21.

51Letter of Albuquerque to D. Manuel of 01-04-1512, in Rêgo, Documentação para a História das Missões, I, 145-52. 
as personal servants, as slaves, but also used as prostitutes, in order to settle men, mostly soldiers, in Eastern positions. ${ }^{52}$

In addition, the extension and the heterogeneity of the Portuguese presence in the East and the Far East was such that one cannot just replicate the conclusions based on the case studies of Goa or the Malabar Coast to all the Portuguese settlements in the region.

As regards their roles and performances as brokers, those women became unavoidable partners in politics and in war. Women can be found assuming roles of local interpreters and messengers in different conflicts involving the Portuguese. They could perform as political leaders with whom the Portuguese had to negotiate or fight, as with the queens of Coulão (Kollam) and Camorim (Kanyakumari), ${ }^{53}$ confronting them at the beginning of their settlement on the Malabar Coast. They might also perform as war ambassadors, appointed by the local holders of power during wartime. ${ }^{54}$ Local women frequently appear in the sources as intermediaries in negotiations. There are several instances in which this is reported, as in Peregrinação by Fernão Mendes Pinto, as for example Nhay Pombaya, a widow of nearly sixty years of age, negotiating in Banta. ${ }^{55}$

On the other hand, one should not forget the role of the Portuguese women. Attempts at religious conversion, especially by Jesuit missionaries, were frequently aimed at the leaders, the local rulers, in order to spread Christianity over all their subjects, in a top-down conversion strategy. In some

52This is not a Portuguese practice particularity.For the British East Indian Company, the use of female slaves as unofficial concubines is evident from the references to the birth of several children of factors and free men of the Madras factory by slave women. The Company records also mention the exploitation of slave women as prostitutes on the island. Cf. Anna Winterbottom, "From Hold to Foredeck: Slave Professions in the Maritime World of the East India Company, c.1660-1720," in Maria Fusaro and AméliaPolónia, eds., Maritime History as Global History (St. John's; Newfoundland: International Maritime Economic History Association, 2011), 95-124.

53Fernão Lopes de Castanheda, Historia do Descobrimento e Conquista da India pelos Portugueses (Lisbon: Typographia Rollandiana, 1833), 215-16.

54Correa, Lendas da Índia, $4^{\text {th }}$ Book, Tome IV, 81-82.

55Fernão Mendes Pinto, Peregrinaçam (Lisbon: Pedro Crasbeeck, 1614), 221-221v. 
cases, princes were brought to be educated in Goa or other Portuguese settlements in India. In other cases, the marriage of local rulers with Portuguese women became a simultaneous or alternative way to ensure, not only conversion to Christianity, but effective acculturation. This is the case of the Maldives ruler, Sultan Hassan IX Svasi Sri Dhirukusalokya MahaRadun. His Christian name was D. Manuel, and he married a Portuguese woman, D. Leonor de Ataíde, daughter of Heitor de Sousa de Ataíde. In India, a second son of the same leader, João, married another Portuguese woman, Francisca de Vasconcelos. ${ }^{56}$ Within this context, Portuguese women were used as alliance builders as much as autochthone and mixed breed women, and they were strategic pieces in political games.

At a different level, D. Juliana Dias da Costa (1658-1733) was a prominent character at the court of the Mughal in the late seventeenth, early eighteenth century. Daughter of the physician Agostinho Dias da Costa and an Armenian slave, this woman held a detached position with the Grand Mogul for over 40 years. She spoke fluent Arabic and Portuguese, and lived as a Christian in Muslim lands. She was reported in Portuguese sources as founder of a number of Jesuit missions in the region. ${ }^{57}$ Her role in the court of the Great Mughal was not even exceptional, seeing the culture, the education and the economic activities of elite women in the Great Mughal, particularly in the seventeenth century. ${ }^{58}$

As much as political agents, these women performed as economic intermediaries. They were in fact essential hubs of trade networks. In the East, the number of Portuguese widows

56Dejanirah Couto, "Uncoup d’épée dans l'eau: la Memoria da tomada da fortalleza de Catifaetl 'expédition à Bassorah (1551)" in Dejanirah Couto and Rui Loureiro, Revisiting Hormuz: Portuguese interactions in the Persian Gulf (Wiesbaden: Calouste Gulbenkian Foundation; Harrassowitz Verlag, 2008), 82-83.

57Rosário Coutinho, Mulheres Aventureiras Portuguesas Espalhadas Pelos Quatro Cantos do Mundo (Lisbon: Esfera dos Livros, 2009); Taymiya R. Zaman, "Visionsof Juliana: A Portuguese Womanatthe Court oftheMughals," Journal of World History 23, no. 4 (2013): 761-91. 
acting on behalf of their deceased husbands illustrates their role as active economic agents. The records repeatedly refer to that, including the classic example of Dona Luisa da Silveira, widow of the former governor of Hormuz, authorized in 1622 to act as shipping manager. ${ }^{59}$ In the Eastern context, considering the roles of autochthone women, this was not uncommon.

As for the Eastern societies, elite women in local courts seem to have exercised economic as well as political power. This depended on the role of women in local societies, heterogeneous as they could be. About the role performed by Asian women in the Indian and Pacific world before the massive arrival of Europeans, Anthony Reid stresses the relatively high autonomy and economic relevance of women in sixteenth and seventeenth-century Southeast Asia, even if claiming that it could not be said that women were equal to men, since there were very few areas in which they competed directly with each other, women having different functions from men. ${ }^{60}$ Their roles would include planting and harvesting rice, weaving, and marketing. Reid also stresses that the important economic role of women explains why the value of daughters was never questioned in Southeast Asia as it was in China, India, and the Middle East: on the contrary, he points out António de Galvão's 1544 statement, according to which, in Southeast Asia, "the more daughters a man has, the richer he is." 61 Tomé Pires notices in 1515 that Melaka benefited a lot from the women street sellers, since they even held a market at night. ${ }^{62}$ António de Galvão describes, in 1544, how women in Birman country were managing the more important mercantile

59Germano da Silva Correia, História da colonização portuguesa na Índia (Lisbon: Agência Geral das Colonias, 1948-1956), 5 vols.; Charles Boxer, A Mulher na Expansão Ultramarina Ibérica (n. p.: Livros do Horizonte, 1977), 98.

60 Anthony Reid, "Female Roles in Pre-Colonial Southeast Asia," Modern Asian Studies 22, no. 3, Special Issue: Asian Studies in Honour of Professor Charles Boxer (1988): 629-45.

61 Antonio Galvão, A Treatise on the Moluccas (c. 1544), probably the preliminary version of Antonio Galvao's lost História das Molucas, edited by Hubert Jacobs S.J. (Rome: Jesuit Historical Institute, 1971), 89.

62 Tomé Pires, 1515, The Suma Oriental of Tomé Pires (London: Hakluyt Society, 1944), 274; Hwang Chung, "Hai Yũ (Words about the sea), 1537”, in Historical Notes on Indonesia and Malaya, Compiled from Chinese Sources (Groeneveldt, 1880), 128. Quoted by Reid, 635. 
business of their husbands and how, surprisingly, Moluccas women were "those who negotiate, do business, buy and sell". ${ }^{63}$ The contributions of Barbara Watson Andaya on the role of women in the pepper trade should also be acknowledged. ${ }^{64}$ As they were active elements in trade and shipping, it was inevitable that the Portuguese had to deal with them as intermediaries in Indian and Inter-Asiatic trade. Explicit evidence of this is, nevertheless, surprisingly scarce, not to say exceptional, in the reports of crown officers, as opposed to what can be said about the West Coast of Africa. Even so, for Macao, the activities of Isabel Reigota are documented. She was a widow of Japanese origin, known for her attempts to reintroduce Jesuits into Japan after their expulsion, as well as her important role in the sandalwood war, this time against the Jesuits' interests. In this judicial quarrel, Isabel Reigota appears as one of the main players in the Mau trade, namely in sandalwood. ${ }^{65}$

Cultural transfers are still another level on which women acted as intermediaries between worlds, since they were agents of linguistic, cultural and knowledge transfers, too. The overall content of this debate points to an unavoidable conclusion: women were, by necessity, elements of cultural transfers between worlds. First of all, as partners and spouses: it was inevitable they would transmit language, practices of hygiene, diets and food preparation rules; house building and aesthetical sense. As mothers they were educators, so their interceptive capacity to transfer to the new generations codes of conduct, ethical behavior and values, beyond religious rites, would be paramount.

Some other ways of cooperation included transfer of knowledge. The example of the centrality of Antonia, the slave of Garcia da Orta, the Portuguese New-Christian doctor

63Galvão, Treatise on the Moluccas, 75. Quoted by Reid, 634.

64 Barbara Watson Andaya, "Women and Economic Change: The Pepper Trade in PreModern Southeast Asia," Journal of the Economic and Social History of the Orient 38, no. 2, Women's History (1995): 165-90.

65Elsa Penalva, Mulheres em Macau: donas honradas, mulheres livres e escravas (séculos XVI e XVII). (Lisboa: CHAM/Centro Científico e Cultural de Macau: 2011), 115-42. 
operating in Goa is striking. In a dialogue between Doctor Orta and Doctor Ruano, she is the one called to assert, correct and give credit to the value of local knowledge. The local authority lay, after all, in a woman whose legal status as a slave would be expected to weaken her social position. ${ }^{66}$

In any case, between resistance, conflict, cheating, defection, intermingling and assimilation, those women, Portuguese and autochthone alike, performed as intermediaries between worlds. Their presence and agency were vital to economic flows between worlds, were essential to the survival of the newcomers, important in negotiations and the access to local knowledge. They were active agents in complex processes of identity construction in colonial set-ups. They were influential in processes of social organization, through their role in family (and on the fringes of the institutionalized families) and in the reconfiguration of colonial social environments.

\section{Final remarks}

Some ideas could be highlighted regarding the importance as brokers and go-betweens in the "Portuguese" State of India and the building up of a global world, arising from the local.

In the first place, globalization is a complex and multidimensional process, which, nevertheless, in its economic, cultural, ethnical, linguistic, and even environmental implications, has more to do with the activities of individual agents crossing all kind of frontiers: linguistic, cultural, geographical, political, religious, rather than with the functioning of national empires. Globalization is based on cooperation, while formal empires present themselves more disposed to imposition mechanisms. One has thus to accept and acknowledge the importance of persistent informal ways of empire building, which either ran against the empires themselves, or use the framework of empires to strengthen their positions. 
Secondly, mechanisms of globalization can be much better appreciated and understood if one looks at the other side of the mirror, and searches for the functioning of mechanisms of cooperation (which involved also ways of deception, desertion and competition) operating among informal networks of individuals. Locality becomes essential for this interplay.

Thirdly, Portuguese overseas expansion as a whole is quite expressive of the ways in which individual agents and selforganized networks worked in favor of the building and maintenance of a polyhedral overseas empire. They were even essential to its maintenance, either by following crown policies, when they were beneficial for their own goals and aims, or by pursuing their own strategies, frequently in rivalry with the state. Understanding the building and collapse of the Portuguese empire implies understanding the manner in which those agents interacted within and outside the borders of the formal empire.

Last, but not least, religion, politics and trade were inextricable domains of individual agency. Processes of imposition, negotiation, and adaptation weaved a web of global interactions between European, and a full range of Asian peoples, on which thorough reflection and research is essential to more fully understand the dynamic, open, complex, non-linear system which characterized the First Global Age. 